\title{
Shadowing Technique; Teaching Listening Skill to ESOL Learners in University
}

Siti Aisyah Ginting ${ }^{1}$

${ }^{1}$ Faculty of Languages and Arts, Universitas Negeri Medan, Indonesia

\begin{tabular}{l}
\hline \hline ARTICLE INFO \\
\hline \hline Article history: \\
Received April 02, 2019 \\
Revised May 03, 2019 \\
Accepted June 15, 2019 \\
\hline
\end{tabular}

Keywords:

Shadowing Technique, Listening Skill, ESOL

\section{Clonflict of Interest:}

None

\begin{abstract}
The purpose of this paper is to report the effect of Shadowing Technique on students' listening skills achievement. Therefore, the experimental research was applied and the technique on collecting the data was administrating pre- and post- tests to the experiment and control groups, which consisted of 40 students in each group. Then, t-test was employed on analyzing the data. As a result, there was a significant difference between the mean of experimental and control groups $(F=8.92, p=$. $003<.05)$. Therefore, there was a significant effect of applying shadowing technique on students' listening skill achievements and the experimental group outperformed the control group. To sum up, the alternative hypothesis was accepted and the null hypothesis was rejected.
\end{abstract}

Funding:

None

Corresponding Author: Siti Aisyah Ginting, Senior Lecturer at English and Literature Department, Faculty of Language and Arts, Universitas Negeri Medan, Indonesia. Email: aisyah_ginting@yahoo.co.id. Tel. $+62821-6156-3963$

Copyright $\left({ }_{0}\right.$ Association of Language Teachers in Southeast Asia. All rights reserved

\section{Introduction}

In instructing and learning English, there are four abilities, which ought to be aced by students to be specific tuning in, talking, perusing and composing. Moreover, among every one of those abilities, listening expertise is the most fundamental aptitude in learning English since listening is the main stage in gaining and learning language before talking, perusing or composing. Accordingly, listening is the extension to ace the three different abilities. In accordance with this, Sevik (2012) expressed that students in learning English will initially tune in, talk, read, and after that compose. Alongside that, listening expertise is the basic part to create different abilities in outside or second language learning (Ghanbari and Hashemian, 2014).

Colleges in Indonesia allot Listening Skill subject began from the first up to the fourth semester. Fundamentally, the primary target of listening expertise is to build up the understudies' appreciation and seeing precisely to what the English speaker says. By and large, most understudies of English as unknown dialect, for example, in Indonesia will in general abstain from Listening aptitude subject in view of its trouble. Schmidt (2016) found in his investigation that listening ability is the most troublesome expertise for an unknown dialect student. At that point explicitly, identified with the primer information, which were gathered on January 2017, it tends to be abridged that $80 \%$ of 
the understudies' listening ability score were still under the passing evaluation which is 70 more than 100. Therefore, the understudies need to retake this subject.

Actually, instructing and learning English is a confused undertaking to do. The instructor needs to locate the reasonable technique to the understudies' needs and setting. Many concur with Brown (2007) who said that there is no a solitary best technique in showing language, accordingly, we, as instructors or educators, should locate the important strategy to the understudies' needs and setting. Truth be told, past instructing listening strategy connected in tertiary level has demonstrated that there was no critical enhancement for understudies' listening abilities. At that point, they are required to be an English educator after graduation while their capacities in English especially in listening appreciation were still a long way based on what being normal. Along these lines, it is vital to assist the teacher with giving a positive effect on the understudies' accomplishment in listening ability. Subsequently, this examination proposed an option in contrast to this condition, which was applying shadowing procedure in instructing and learning of English as unknown dialect in English Department UNIMED.

Shadowing has turned into a fascinating theme with regards to English language instructing and learning field as of not long ago. Essentially, as per Tamai (2002), shadowing is a listening exercise in which the English students track the heard discourse and rehash it as precisely as could be allowed while listening mindfully to the approaching data. What's more, Tanaka (2004) brought up that shadowing drives student to imitate the heard discourse with in a brief timeframe. She said that through this activity, the students' listening understanding (responsive aptitude) and generation ability are featured. As needs be, this technique ought to be fitting to the understudies of English in Indonesia.

The fundamental goal was to inspect in the case of shadowing could give a constructive outcome to the accomplishment of English tertiary students who were in the principal semester. In the mean time, the particular destinations of this investigation were to 1) examine the significant difference of the learners' listening scores between learners taught through shadowing technique and classical method, and 2) examine the significant effect of shadowing technique on the learners' achievements of listening skill in tertiary level

\section{Literature Review}

\subsection{Shadowing Technique}

As indicated by Shiki et al., (2010), shadowing can be characterized as a brief procedure of verbal articulation redundancy, while rehashing is a disconnected assignment since it supplies students with quiet stops to make the sounds. What's more, Kadota (2007) expressed that the redundancy procedure approaching discourse and controlling the shadowed material possesses numerous regions of the students' cerebrums, especially the focal point of language. By the by, shadowing procedure really is intellectual and dynamic exercises where the students trail the heard discourse and unmistakably verbalize it while listening ceaselessly (Tamai, 1997).

Moreover, the advantages of the shadowing strategy are: right off the bat, enacting the procedure of base up and top-down (Tamai, 1992), besides, echoic memory is worked to keep up the approaching sounds data all the more accurately (Kadota, 2007). Understudies can invest more energy in breaking down the new data. Moreover, Someya (1996) said that shadowing system helps to improve the feeling of prosody: the beat, pitch, and highlight of discourse. Prosody is the significant component in correspondence in light of the fact that up to $40 \%$ of correspondence importance is caught by prosody.

Basically, shadowing system has been utilized in Japan in language instructing setting. For example, Murphey (2001), Takizawa (2002) Kadota and Tamai (2005) expound the assortments in ESL/ESOLeducating setting. Accordingly, Takizawa's model was connected to this examination in light of the fact that in his model there are translation exercises. As indicated by specialist, this sort of the shadowing procedure is fitting to Indonesian ESOLshowing setting in light of the fact that Hamada (2011) cautioned that numerous understudies accept that they need to decipher each word they hear promptly, which impacts to diminish self-viability through interpretation disappointment.

SALTeL Vol. 2, No. 2, July 2019: 83-87 
At that point, to make understudies feel tested in working on shadowing procedure, different exercises like interpretation; quiet perusing and just listening are very suggested (Shiki et al., 2010). It implies that handing-off shadowing strategy exclusively would not improve the students' accomplishments in listening aptitude. In this manner, this examination adhered to the guidance prescribed by Takizawa (2002).

\subsection{Previous Studies of Shadowing Technique in Listening Skill}

Takizawa (2002) affirmed that the shadowing procedure is a viable strategy to improve base up procedure in listening aptitude, train to secure increasingly effective listening appreciation. Additionally, students ascend to improve articulation, get more centers, and become accustomed to characteristic speed also. In this way, understudies can get numerous advantages and listening abilities improvement from shadowing way.

Genuinely, the adequacy of shadowing procedure has been analyzed in study hall explore. The examination was led to 112 understudies on demonstrating the compelling and down to earth methods to actualize shadowing in the study hall by utilizing course reading (Suzuki, 2007). Furthermore, Tamai (2005) completed an exploratory investigation into 45 students in each gathering of two. It was accepted that shadowing helps frail understudies. He partitioned each gathering of 45 understudies into three unique levels. After 13 exercises, the aftereffect of the shadowing gatherings exhibited that the frail and the normal understudies had huge upgrade. Other than that, Onaha (2004) showed 43 tertiary students through shadowing system and transcription and inferred that the blend of the activities had adequately improved the students' listening understanding aptitudes.

Hypothetically and for all intents and purposes in Japan, the shadowing procedure has given numerous verifications in ESOLsetting that it could improve the understudies' accomplishment in listening perception abilities. Hence, this system must be utilized in instructing listening expertise in Indonesia since Indonesian likewise perceives English as a Foreign Language (EFL).

\subsection{Hypothesis}

In accordance with the literature review, the hypothesis was formulated as null hypothesis (Ho) and alternative hypothesis (Ha) as below:

Ho = There was no significant effect of shadowing technique on tertiary ESOL learners' achievement in listening skill.

$\mathbf{H a}=$ There was significant effect of shadowing technique on tertiary ESOL learners' achievement in listening skill.

\section{Methodology}

\subsection{Subjects of Study}

There were 80 students who were involved in this study. The students were divided in to two groups named experiment group and control group. Each group consisted 40 students. Moreover, the ranges of their ages were from 17 to 19 . The subjects were selected randomly from 250 students at English Department, Universitas Negeri Medan, Indonesia. In addition, the students were in the first semester and sitting for Listening 1 subject.

\subsection{Materials}

IELTS 2 English for International Education $2^{\text {nd }}$ Edition (2013) was selected for this research. This book is written by Loui Harrison, Caroline Cushen and Susan Hutchison and published by HEILE CHENGAGE Learning. There are three reasons why this book was considered appropriate for this study. Firstly, the listening material contains different level of the difficulties. Secondly, since the students of English Language and Literature Department Universitas Negeri Medan are expected to be English teachers, the suitable textbook for them is IELTS for academic purpose. Thirdly, the test items in official IELTS test maintained reliability. 


\subsection{Technique of Analyzing the Data}

To measure the effect of shadowing technique on the students' achievement in listening skill, an analysis of t-test in Statistical Package for Social Science (SPSS) was employed to tabulate the data (pre- and post-tests of listening).

\section{Results and Discussion}

For data analysis, the students listening answers' sheets were scored. Then, the raw data were pluged in into SPSS software for further analysis. To compare the two sets of scores, descriptive statistics and t-test were conducted and the result is presented as follows.

Table 2: Group Statistics of Mean

\begin{tabular}{lllllll}
\hline & Group & $\mathrm{N}$ & Mean & $\begin{array}{l}\text { Std. } \\
\text { Deviation }\end{array}$ & $\begin{array}{l}\text { Std. } \\
\text { Mean }\end{array}$ & Error \\
\hline Listening & Control & 40 & 3.15 & .39 & .07 & \\
\cline { 2 - 7 } Achievement & Experiment & 40 & 6.72 & .52 & .09 & \\
\hline
\end{tabular}

As can be seen in table 2, the experimental group had a higher mean in comparison to the ones in the control group (6.72> 3.15), which Standard Deviation is .52 and 0.39 respectively. Thus, this current study, the experimental group surpassed the control group. To see the significant different of both groups, the descriptive statistic of t-test is presented on the table below.

Table 3: Descriptive Statistic of $t$-test

\begin{tabular}{lllll}
\multicolumn{3}{c}{$\begin{array}{c}\text { Levene's Test for } \\
\text { Equality of Variances }\end{array}$} & \multicolumn{3}{c}{ t-test for Equality of Means } \\
\hline F & Sig. & t & df & $\begin{array}{l}\text { Sig. } \\
\text { (2-tailed) }\end{array}$ \\
8.92 & .003 & 3.20 & 57 & .000 \\
\hline & & 3.20 & 52.94 & .000
\end{tabular}

From Table 3, the test was found that Levene's test for equality of variances examined for the present analysis, $(F=8.92, p=.003<.05)$. Owing to this assumption, a $\mathbf{t}$ statistic assuming the variance was computed. Moreover, this test was found to be statistically significant, $\mathrm{t}(57)=3.20, \mathrm{p}$ $<.05$. The mean of the experimental group was more than double of the control group's mean. The difference is also displayed graphically in figure 1. This proves that shadowing was an effective technique in enhancing the listening comprehension skills of the participants in the experimental group. This difference is also statistically significant. In other words, the alternative hypothesis that shadowing techniques give positive impact on tertiary ESOLlearners' listening skill achievement is confirmed.

Hence, the null hypothesis of the study, which stated that using shadowing technique had no significant effect on tertiary ESOL learners' listening skill achievement was rejected with those receiving the treatment outperforming significantly those in the control group. In other words, the alternative hypothesis of the study, which stated that there is a positive impact of Shadowing technique on tertiary ESOL learners' listening skill achievement, was accepted.

\section{Conclusion}

From the result and discussion, it can be concluded that the shadowing technique had a significant effect on the students' achievement in listening skills since there was a significant difference between the mean scores of experimental and control groups. In this study, experimental group outperformed the control group. Furthermore, this technique is suitable to the English for Speakers of Other Language (ESOL) learners because the process of acquiring and learning the language is very systematic and contextual. Therefore, this shadowing technique is very much suugessted fou 
use in listening classroom for the better outcomes or students' achievement as especially to the countries, which recognized English as Foreign Language such as Indonesia, Japan, China, and etc.

\section{REFERENCES}

Brown, H. D. (2007). Principles of language learning and teaching . NY: Pearson Education.

Ghanbari, F., \& Hashemian, M. (2014). The Effects of English Songs on Young Learnerse Listening Comprehension and Pronunciation. International Journal of Language Learning and Applied Linguistics World, 6(3), 337-345.

Hamada, Y. (2011a). A study on a learner-friendly shadowing procedure. Journal of the Japan Association for Developmental Education, 6(1), 71-78.

Hamada, Y. (2011b). Improvement of listening comprehension skills through shadowing with difficult materials. Journal of Asia TEFL, 8(1), 139-162.

Kadota, S. (2007). Shadowing to ondoku no kagaku [Science of shadowing and oral reading]. Tokyo: Cosmopier.

Murphey, T. (2001). Exploring conversational shadowing. Language Teaching Research, 5(2), $128-155$.

O'Connel, S. (2010). Focus on IELTS; New Edition. Edinburg: Pearson Longman.

Onaha, H. (2004). Effect of shadowing and dictation on listening comprehension ability of Japanese ESOLlearners based on the theory of working memory. JACET Bulletin, 39, 137148.

Sevik, M. (2012). First step to effective listening:"Listen and show" songs.International Journal of English and Education, 1(1).

Shiki, O., Mori., Y., Kadota, S., \& Yoshida, S. (2010). Exploring differences between shadow- ing and repeating practices. Annual Review of English Language Education in Japan, 21, 8190.

Someya, Yasumasa (1996). Tsuyaku kunren syuho to sono ippangogaku gakusyu heno ouyou ni tsuite. [A tool for interpreter training technique for language enhancement]. Tsuyaku Rironkenkyu [Interpreting Research], 11.

Suzuki, K. (2007). Shadoing wo moichita Eigo choryoku kojo no shido ni tuite no kensho [Investigation on the instruction for listening comprehension through shadowing]. STEP Bulletin, 19, 112-124.

Tanaka, M. (2004). Tsuuyaku kunrenhou wo riyou shita eigo kyouikuno jissai to mondai. [Current pedagogical issues in teaching interpreting at undergraduate level]. Interpreting Studies No.4. 63-82.

Tamai, K. (1992). The effect of "shadowing” on listening comprehension. Unpublished Master's thesis, School of International Training, Brat- tleboro, Vermont.

Tamai, K. (1997). Shadowing no koka to chokai process niokeru ichizuke. [The effectiveness of shadowing and listening process]. Current English Studies, 36, 105-116.

Tamai, K. (2002). On the effects of shadowing on listening comprehension-Keynote lecture at the 3rd Annual Conference of JAIS. Interpretation Studies,2, 178-192.

Tamai, K. (2005). Listening shidoho to shite no shadowing no koka ni kansuru kenkyu [Research on the effect of shadowing as a listening instruction metho]. Tokyo: Kazama.

Takizawa, M. (2002). Gogakukyokaho toshiteno tsuyakukunrenho to sono oyorei [Interpreter training techniques and their application as a tool for language enhancement]. Bulletin of Hokuriku University, 26, 63-72. 